MATEC Web of Conferences 17, 01002 (2014)

DOI: $10.1051 /$ matecconf/ 20141701002

(C) Owned by the authors, published by EDP Sciences, 2014

\title{
Investigation of Wastewater Pollution at Clan Jetty, Penang
}

\author{
Fazilah Md Razak ${ }^{1}$, Nik Fuaad Nik Abllah ${ }^{2, a}$ \\ ${ }^{1,2}$ School of Housing, Building and Planning, Universiti Sains Malaysia, 11800, Penang, Malaysia
}

\begin{abstract}
This study aims to determine the level of wastewater pollution at Clan Jetty, Penang. 20 locations were chosen for water sampling around the jetties. Experiments were conducted to investigate the parameters, namely, temperature at each point, Chemical Oxygen Demand (COD), Biochemical Oxygen Demand (BOD), pH, Dissolved Oxygen (DO), the presence of Coliform and E. coli, Nitrate Nitrogen, Ammonical Nitrogen, Suspended Solids, Oil and Grease as well as Total Phosphorus (TP). Laboratory results showed that Point $1 \mathrm{~A}$ was the most polluted location compared to other sampling points. The highest COD recording was $5824 \mathrm{mg} / \mathrm{L}$ at Point $1 \mathrm{~A}$ and the lowest amount of 103 $\mathrm{mg} / \mathrm{L}$ was recorded at Point 4 . This study demonstrates that the absence of a sewerage system contributes to marine pollution around the jetties. Thus, a sewerage system is the best solution to improve water quality around the jetties in the future.
\end{abstract}

\section{Introduction}

Water is one of the most important resources given by God Almighty to all humans. An understanding of the process involved in maintaining and preserving the quality of water is needed to give people an assurance of health and safety. People depend on urban resources (especially water resources) as well as adequate basic knowledge of the current status of their surrounding physical environment.

In Malaysia, seaside environments are generally rich in marine biodiversity (Ching, 1998) and beach areas in Malaysia are one of the main contributors to Malaysia's ecotourism industry (Hassan, 2008). However, marine environments in Malaysia continue to face serious problems, mostly due to the worsening of water pollution over the years. Rapid development along coastal areas and influences from the mainland has been identified as the major factor affecting marine pollution (Mustafa and Mariani, 2011). Suspended solid, oil and grease as well as Escherichia coli (E. coli) have been identified as the main contaminants of such coastal environments around Malaysia.

The biggest source of pollution by volume of waste and pollutants discharged to the land comes from sewage systems, with the greatest contribution to marine pollution coming from land based activities such as wastewater, solid waste, and agricultural run-off (BOBLME, 2011). The ocean floor is abundant with natural resources for marine life as well as for humans. The ocean provides oil and gas for energy needs worldwide, sources of seafood and habitats for marine life. It is also relied upon for moving materials and goods.

Improper disposal and inadequate treatment of sewage effluents poses a serious threat of surface and groundwater pollution as well as soil contamination (Adepelumi et al., 2005). Disposing of sewage effluents into the environment without any treatment leads to loss of proteins and essential

\footnotetext{
${ }^{\mathrm{a}}$ Corresponding author : nfuaad@usm.my
} 
minerals that then accumulate in the kidneys because increased heavy metals like cadmium $(\mathrm{Cd})$ (Seiler et al., 1998). According to the Malaysia Environmental Quality Report 2012 by the Department of Environment Malaysia (DOE), the number of excellent and good marine water quality stations had decreased while the number of moderate stations had increased in terms of the Marine Water Quality Index (MWQI) for 2010 - 2012. Thus, to preserve the earth's biodiversity, it is vital for humans to protect and control marine environments from water pollution. This study aims to assess the level of wastewater pollution at Clan Jetties in Penang, Malaysia.

\section{Methodology}

For the purpose of this study, 20 points were selected for water sampling. These points are shown in Fig. 1.

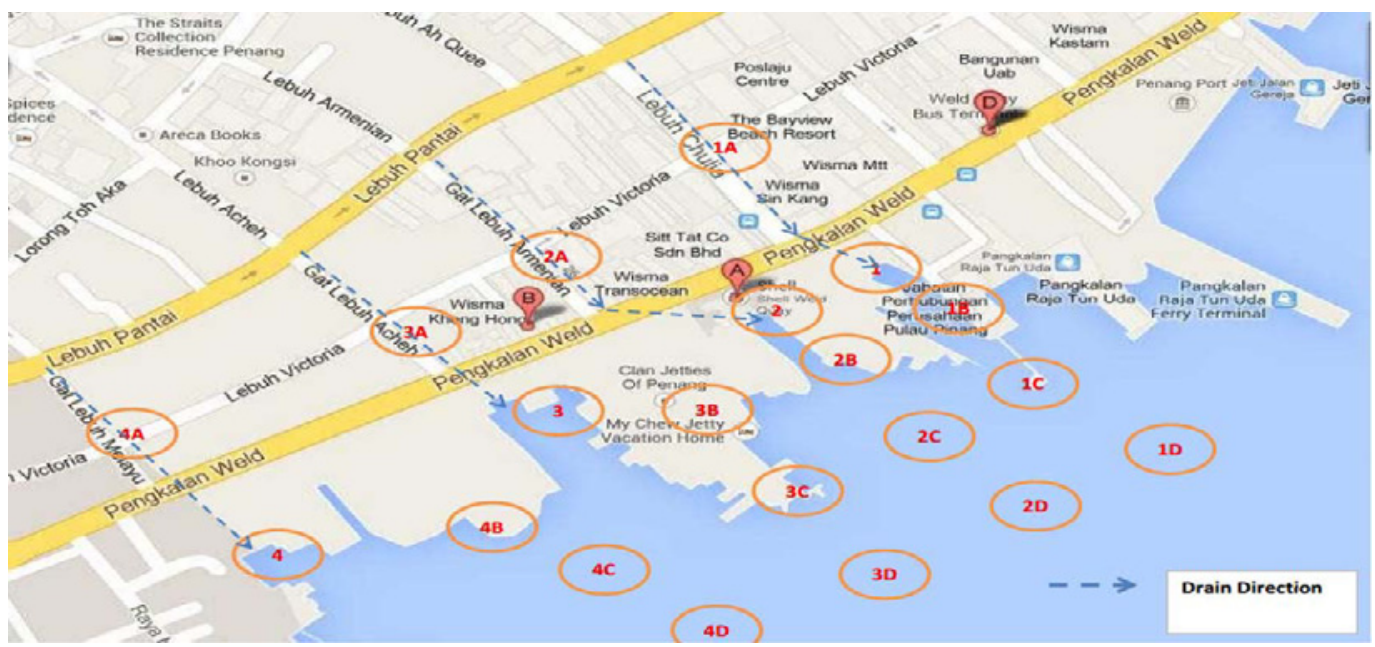

Fig. 1: Sampling points.

Sample collection and preservation: Water samples from each point were collected using $20 \mathrm{~L}$ bottles and were stored inside a cool room at a temperature of $4^{\circ} \mathrm{C}$ to maintain their chemical and biological properties.

At each point, a $25 \mathrm{~L}$ sample was collected and in situ measurements of water temperature were recorded. All the samples taken were kept in a cold room to lower microorganism degradation activity. The water samples were analysed in the laboratory for Chemical Oxygen Demand (COD), Biochemical Oxygen Demand (BOD), pH, Dissolved Oxygen (DO), the presence of Coliform and E. coli, Nitrate Nitrogen, Ammonical Nitrogen, Suspended Solids, Oil and Grease, and Total Phosphorus (TP).

\section{Results and Discussion}

In an effort to protect locals from the health risks and other adverse consequences of poor water quality, water quality standards have been established. According to Interim National Water Quality Standards for Malaysia (INWQS), the COD freshwater value for point $1 \mathrm{~A}$ was $5824 \mathrm{mg} / \mathrm{L}$. Such a high value means the water is unsuitable for any type of use or activity. At this same location, there were no points where a COD below $100 \mathrm{mg} / \mathrm{L}$ was recorded. The restricting presence of high COD may indicate faecal contamination from humans or organic matter from non-human sources (UNDSA, 2007).

According to water classifications and uses, Class I relates to the conservation of natural environments which is for water supplies where practically no treatment is necessary and for fisheries 
with very sensitive aquatic species. Class IIA is used for water supplies which need conventional treatment and fisheries raising sensitive aquatic species. Class IIB is for recreational use with body contact. Class III is used for water supplies which need extensive treatment, fisheries raising common types of economic value fish and tolerant species, and livestock drinking water. Class IV is used only for irrigation purposes. The lowest class of water is Class $\mathrm{V}$ which is unsuitable for any of the activities mentioned above. In the context of BOD value, the majority of the test locations fall into Class $\mathrm{V}$ as they are not suitable for any use. The highest BOD was recorded at point $1 \mathrm{~A}$ with a value of $2790 \mathrm{mg} / \mathrm{L}$ and the lowest BOD value was $1 \mathrm{mg} / \mathrm{L}$ at point $2 \mathrm{C}$ which is classified as Class II.

Furthermore, the $\mathrm{pH}$ value recorded for Point $1 \mathrm{~A}$ was the lowest at 4.60 , while Point $4 \mathrm{D}$ had a higher $\mathrm{pH}$ value of 8.2. Most bodies of water had $\mathrm{pH}$ values ranging from 4 to 8 . If the $\mathrm{pH}$ of water falls below 6, it will have harmful ecological effects (Lenntech, 2012). Extreme pH can kill adult fish and invertebrate life directly and can also damage growing fish. When the $\mathrm{pH}$ of freshwater becomes highly alkaline, the effects to marine life include death and damage to outer surfaces.

Half of the test sites tested safe in the ammonical nitrogen test. The water in these location has healthy levels as long as they remain below $2.7 \mathrm{mg} / \mathrm{L}$. The points were $1 \mathrm{~B}, 1 \mathrm{D}, 2 \mathrm{~B}, 2 \mathrm{C}, 2 \mathrm{D}, 3 \mathrm{~B}, 3 \mathrm{C}$, $3 \mathrm{D}, 4 \mathrm{C}$, and 4D. The highest amount of ammonical nitrogen value was found at Point $2(254.2 \mathrm{~m}$ $\mathrm{mg} / \mathrm{L}$ ). This could be due to the runoff from the surrounding premises using the water as a provisional septic tank. This high value suggests that the water is not suitable for any type of use.

The experiments conducted proved that 6 points showed the lowest value of DO which were below one. These locations were Point 1, Point 1A, Point 2, Point 2A, Point 3, Point 3A, Point 3B Point 4, and Point 4A. In comparison, the highest DO was recorded at Point 4D with a reading of 6.94 $\mathrm{mg} / \mathrm{L}$. According to INWQS, the lower the value of DO, the more polluted the water body is. The oxygen dissolves by diffusion from the surrounding air and waste products of photosynthesis. Only green plants and some bacteria are able to go through the process of photosynthesis. Thus, in this case, Points 1B, 1C, 1D, 2B, 2C, 2D, 3C, 3D, 4B, 4C, and 4D may all potentially be suitable for living marine life because of their high $\mathrm{DO}$ values.

Coliforms are bacteria that are always present in the digestive tracts of animals, including humans, and are found in their waste. Total Coliform includes bacteria that are found in the soil and in water that has been influenced by surface water. E. coli is the major species in the faecal Coliform group. Consequently, E. coli is considered to be the species of Coliform bacteria that is the best indicator of faecal pollution and of the possible presence of pathogens (APEC, 2012). Based on INWQS, a high presence of total Coliform and E. coli is harmful for outer body contact. All points in the study showed the presence of both types of bacteria with a maximum value at Point 1 along Lebuh Chulia and with E. coli of $2.1 \times 10^{\wedge} 6 / 100 \mathrm{ml}$. This clearly shows that the study area is severely polluted with faecal matter. Further proof of this comes from the land-use and sewerage asset inventory GIS Map which confirmed that there is quite a large area in which in-situ septic tanks are used.

The experiments conducted showed that Point 3B had the lowest value of phosphorus which was below $0.20 \mathrm{mg} / \mathrm{L}$, and highest value was at Point $1 \mathrm{~A}(40.8 \mathrm{mg} / \mathrm{L})$. These values are considered high as the naturally occurring levels for total phosphorus are generally less than $0.03 \mathrm{mg} / \mathrm{L}$. A high concentration of phosphorus allows plants to take in more nitrogen before the phosphorus is depleted. Thus, when the amount of phosphorus is sufficient, elevated concentrations of nitrates will lead to algal blooms.

The highest value of nitrate $(5.2 \mathrm{mg} / \mathrm{L})$ was recorded at Point $1 \mathrm{~A}$. Meanwhile the lowest nitrate level was $0.3 \mathrm{mg} / \mathrm{L}$ at Point 4 . Overall, the standard nitrate value was below $0.5 \mathrm{mg} / \mathrm{L}$. Thus, results showed that only 3 points (Point 3, Point 3B, and Point 4) were considered to have acceptable nitrate values to support surrounding marine life.

Oil and grease $(\mathrm{O} \& \mathrm{G})$ are an important parameter for water quality and safety. They can cause surface film sand shoreline deposits leading to environmental degradation, and they can induce human health risks when discharged in surface or ground waters. Additionally, oil and grease may interfere with aerobic and anaerobic biological processes and lead to decreased wastewater treatment efficiency. Regulatory bodies worldwide have set limits for oil and grease in order to control the amount entering natural bodies of water or reservoirs through industrial discharges, and also to limit 
the amount present in drinking water. For this experiment, the $O \& G$ values were the highest amount Points 1A-4A where the main drains lead to Clan Jetties' shores. These are the drains along Lebuh Chulia (1A: 214mg/l), Gat Lebuh Armenian (2A: 422mg/l), and Gat Lebuh Melayu (4A: 524mg/l). All of these values are well above the accepted value of $10 \mathrm{mg} / 1$ for Standard B of the EQA. The landuse GIS Map showed indicated many premises, especially restaurants and garages in the study catchment area, which probably dispose of partially treated or untreated O\&G directly into the drains.

For suspended solids measurement, Point $1 \mathrm{~A}$ had the highest value at $2734 \mathrm{mg} / \mathrm{L}$, making it unsuitable for any sort of use. Readings for suspended solids indicated that 12 out of the 20 points studied had values lower than $300 \mathrm{mg} / \mathrm{L}$. This categorizes them as Class I to Class IV, in which the water is safe to use.

\section{Conclusion}

As a conclusion, the most polluted water was at Point 1A which received the worst readings for the majority of the tests that were conducted. In comparison to the other test locations, Point $1 \mathrm{~A}$ had the worst reading for $\mathrm{pH}$ value, Biochemical Oxygen Demand (BOD), Chemical Oxygen Demand (COD), Nitrate Nitrogen, Suspended Solids, and Phosphorus as shown in Figure 2, Figure 3 and Figure 4. It was found that all of the test locations measured high in terms of chemical oxygen demand. This points to high levels of pollution. Biological Oxygen Demand (BOD) levels in this study were higher due to the high demand for oxygen, indicating that a lot of oxygen is used by microorganisms to decompose organic waste. Higher amounts of nitrates and phosphates in a body of water also contribute to high BOD levels where they plant nutrients and cause plant life and algae to grow quickly but also die quickly. This contributes to the amount of organic waste in the water, which is then decomposed by bacteria and results in a high BOD level. When BOD levels are high, dissolved oxygen (DO) levels decrease because the oxygen that is available in the water is being consumed by the bacteria. Since less dissolved oxygen is available in the water, fish and other aquatic organisms may not survive. Hence, the jetties area is no longer suitable for fishing. Presence of faecal coliform (E. Coli) at all of the study locations indicates pollution from sewage wastewaters. Therefore, proper a sewerage system should be planned and put into place in order to overcome these problems.

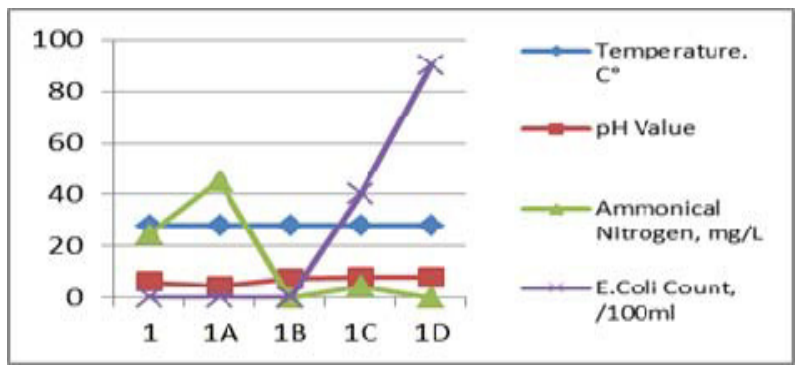

Figure 2: Point $1(\mathrm{~A} \sim \mathrm{D})$

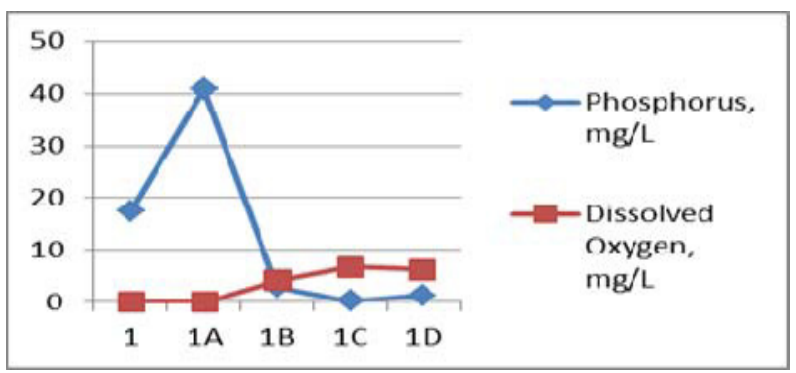

Figure 3: Point 1 (A D) 


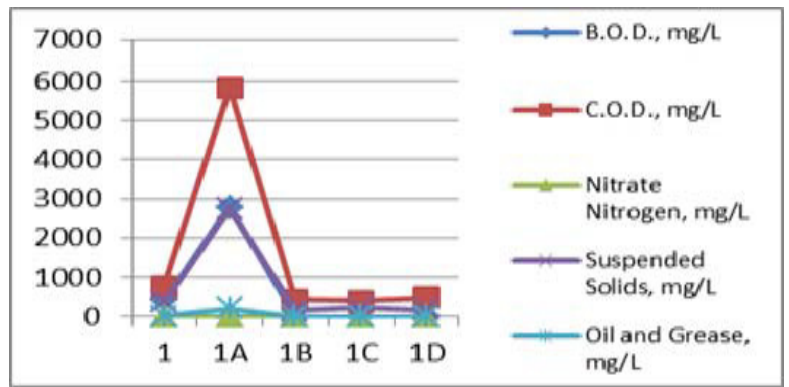

Figure 4: Point $1(\mathrm{~A} \sim \mathrm{D})$

\section{References}

1. BOBLME, 2011. Bay of Bengal Large Marine Ecosystem: Country Report on PollutionMalaysia BOBLME-2011 Ecology-11. In: Ibrahim, Z.Z., M.P. Zakaria, N.M. Tahir, S. Kasmin, A.M. Amiruddin, N. Ismail and K. A. Rahim (Eds.)

2. Ching, L.L., 1998. Marine Protected Areas and Tourism in Malaysia. Paper Presented at the IUCN Vietnam Consultation Meetings for Hon Mun Marine Protected Area, Nha Trang, Vietnam.

3. DOE (Department of Environment), 2012. Malaysia environmental quality report 2012. Department of Environment, Petaling Jaya.

4. Hassan, H., 2008. Ten Years After Asian Financial Crisis 1998: Tourism Growth in Malaysia. Integration Dissemination, pp: 51-56.

5. Lenntech, B.V., 2012. Acids \& Alkalis in Freshwater. Retrieved from: http://www.lenntech.com/aquatic/acids-alkalis.htm, (Accessed on: March 30, 2012).

6. Mustafa, M. and A. Mariani, 2011. The application of law on pollution control towards marine biodiversity conservation in Malaysia. Proceeding of International Conference on Environment and BioScience. Singapore.

7. Sivalingam, P.M., 1984. Ocean disposal and land reclamation problems of Penang, Malaysia. Conserv. Recycling, 7 (2-4): 85-98.

8. UNDSA (United Nations. Dept. of Social Affairs), 2007. Indicators of Sustainable Development:Guidelines and Methodologies. United Nations, New York. 